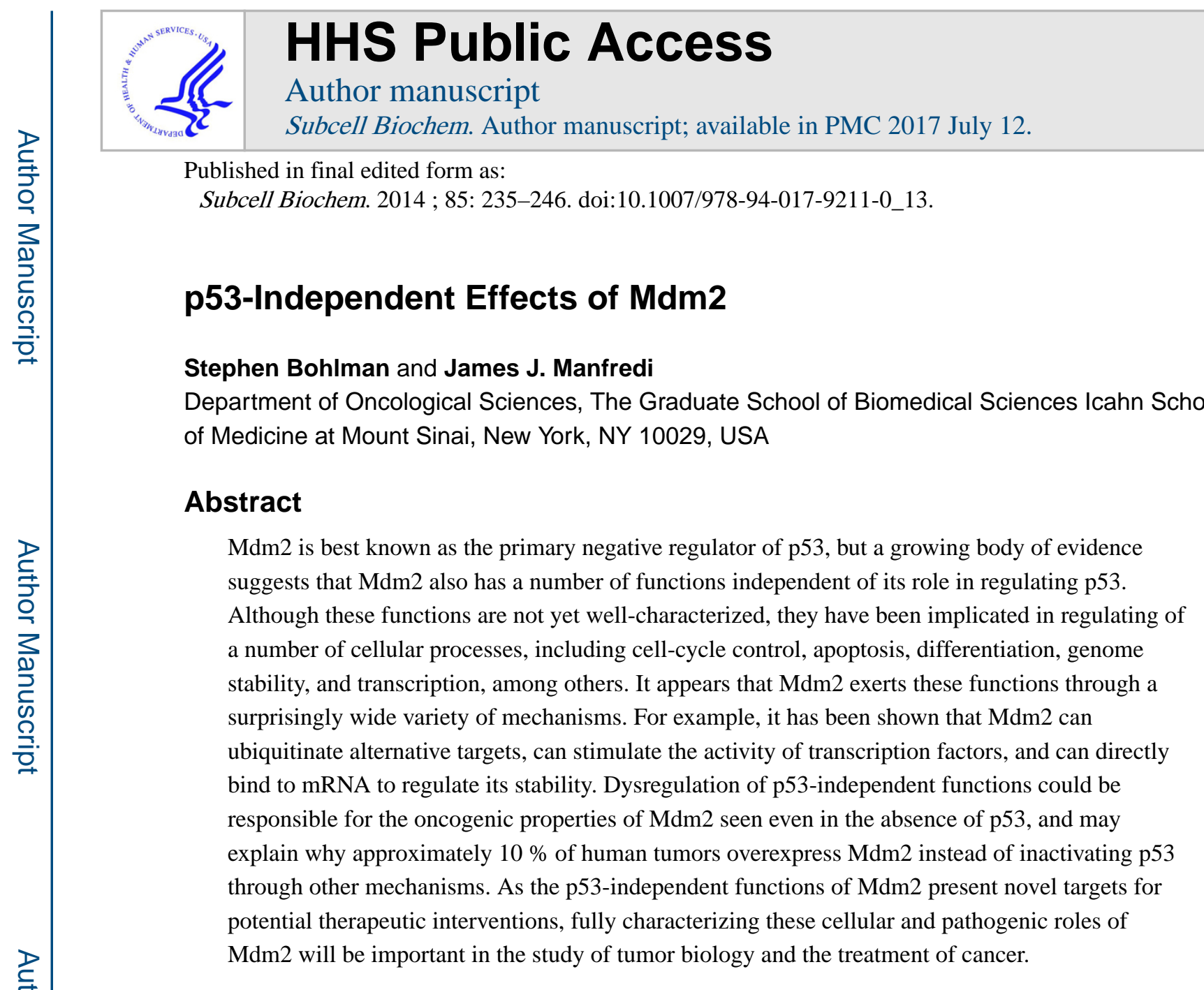

\title{
Keywords
}

Mdm2; p53; Oncogenesis; Ubiquitination

\begin{abstract}
$\operatorname{Mdm} 2$ (murine double minute 2 homolog) is best known for its role as a negative regulator of the tumor-suppressor p53. Due to the ability of p53 to induce cell-cycle arrest and apoptosis, tight regulation of this protein is necessary for normal cellular growth and development. The primary way this regulation is accomplished is through interaction with Mdm2 [26]. Mdm2 is a E3 ubiquitin ligase that ubiquitinates p53 and targets it for proteasomal degradation $[15,17,49]$. Mdm2 is also able to directly bind the $\mathrm{N}$-terminus of p53, inhibiting its activity as a transcription factor for anti-proliferative genes [39]. Mdm2 itself is a transcriptional target of $\mathrm{p} 53$, as the $M d m 2$ gene possesses a sequence-specific recognition site for $\mathrm{p} 53$ within an internal promoter [23, 51]. In this manner, a negativefeedback loop is established, whereby p53 transactivates its own inhibitor. In support of such a regulatory loop, studies of p53 kinetics have shown that elevated levels of p53 following DNA damage decrease in a series of dampened oscillations [29].
\end{abstract}


In response to various stress signals, the Mdm2-p53 interaction is disrupted. Genotoxic stress causes p53 to undergo phosphorylation and acetylation at a number of residues [1, 54]. However, studies have shown that these modifications are not inherently critical to p53 transactivation function, and are only necessary to counter Mdm2 regulation [13, 58, 61]. This suggests that the primary function of these post-translational modifications are the disruption of the Mdm2-p53 interaction. A number of other mechanisms for regulating this have been characterized. Of note is the inhibition of Mdm2 by either $\mathrm{p} 14^{\mathrm{ARF}}$ in response to oncogenic signaling [53] or several ribosomal proteins in response to ribosomal stress [72].

The importance of the Mdm2-p53 relationship to normal cellular development was dramatically illustrated by the homozygous deletion of $M d m 2$ in mice, which results in lethality at the blastocyst stage due to aberrant apoptosis. Strikingly, this phenotype can be completely rescued by the concomitant deletion of p53 [20,41]. Recently, it has been demonstrated that although $\mathrm{p} 53$ transactivation of Mdm2 is necessary for a normal DNA damage response, p53-independent basal expression levels of Mdm2 are sufficient for regulation of p53 in most tissues under homeostatic conditions. This was demonstrated by the use of a transgenic mouse model in which basal levels of Mdm2 are expressed from its p53-independent promoter, but has lost p53-inducible Mdm2 expression [38, 47].

Disruption of the p53 pathway is critical for the development of cancer, as demonstrated by the fact that over $50 \%$ of human tumors contain p53 mutations [16]. Therefore, it is unsurprising that Mdm2 overexpression has been also been implicated in tumorigenesis as an alternative method of inactivating p53 [30]. In one such study, $M d m 2$ was found to be overexpressed in $7 \%$ of 3,889 human tumor samples [40]. The highest frequencies of Mdm2 overexpression were found in soft-tissue sarcomas (20\%) and osteosarcomas (16\%), while other tumor types, such as leukemias, lymphomas, and pancreatic carcinomas, showed little Mdm2 overexpression. Importantly, there is a negative association between amplification of Mdm2 and mutation of $\mathrm{p} 53$ [45]. This association holds potential clinical implications in the possibility of developing therapeutics that restore $\mathrm{p} 53$ function through the inhibition of Mdm2. Indeed, this is the rationale that underlies the investigation of Nutlin-3, a smallmolecule inhibitor of the $\mathrm{Mdm} 2 / \mathrm{p} 53$ interaction, as a potential therapy in cancers that retain functional p53 [27, 52].

\section{Mdm2 and Cancer}

Consistent with its expected role in p53 regulation, ubiquitous overexpression of Mdm2 in transgenic mice predisposes them to spontaneous tumor formation. Surprisingly, however, when Mdm2 is overexpressed in mice in a p53-null background, an increased incidence of sarcomas is observed relative to p53-null mice alone [21]. This suggests that Mdm2 overexpression can also promote tumorigenesis through p53-independent mechanisms. This finding corroborated earlier reports that $\mathrm{Mdm} 2$ is able to transform cells in vitro, independent of p53 [3]. The increased rate of sarcomas in these mice also parallels the high rate of Mdm2 amplification in human sarcomas. Targeted overexpression of Mdm2 to mammary gland tissue led to the production of polyploid mammary epithelial cells in both p53+/+ and p53-/- backgrounds, suggesting a p53-independent role for Mdm2 in the regulation of DNA synthesis and cell-cycle progression [34]. 
In addition to mutations and changes in expression levels, gene activity can also be regulated through alternative splicing of mRNA. Studies of Mdm2 mRNA splicing showed multiple different-sized transcripts and protein isoforms that vary in their ability to bind to p53 [3, 14]. Analysis of Mdm2 mRNA in human ovarian and bladder cancer samples showed the presence of alternative and aberrant splice variants not found in normal tissue. Interestingly, four out of the five identified alternative transcripts contained partial deletions of the p53binding domain, and expression of these isoforms in vitro confirmed their inability to interact with p53. However, all of the alternative transcripts were able to transform NIH 3 T3 cells, indicating an oncogenic property for these transcripts independent of p53 [55]. Similar transcripts have also been identified in glioblastomas, breast carcinomas, pediatric rhabdomyosarcomas, and oral squamous cell carcinomas [2, 37, 33, 50]. In total, over 40 different alternative splice variants have been identified in human tumors, most of which lack the p53-binding domain. Although the exact function of these splice variants is unknown, the fact that multiple splice variants are associated with specific tumor types, and that most of these splice variants do not interact with p53, suggest that these aberrant isoforms may play a $\mathrm{p} 53$-independent role in promoting tumorigenesis.

Although initial studies suggested that overexpression of Mdm2 and mutation of p53 were mutually exclusive in human tumor samples, this was later found to not be the case in certain tumor types. Although the majority of soft-tissue sarcomas contain one or the other, a significant proportion of tumor samples exhibit both an overexpression of Mdm2 and mutation of p53. Interestingly, it was found that there is a significant correlation between tumors containing changes in both proteins and poor patient prognosis [7]. Another confirmatory study showed that the effect on patient survival of Mdm2/p53 cooverexpression was greater than the additive effects of each independently [67]. Additionally, high levels of Mdm2 mRNA expression are correlated with an earlier age of onset of soft-tissue sarcomas [60]. Altogether, these findings point to Mdm2 having p53independent effects in the process of tumorigenesis.

\section{p53-Independent Effects of Mdm2}

How might such p53-independent effects occur? Although the regulation of p53 degradation is by far the most extensively characterized function of $\mathrm{Mdm} 2$, a number of other functions have been described.

Since Mdm2 is an E3 ubiquitin ligase, a straightforward hypothesis would be that Mdm2 ubiquitinates other proteins in addition to $\mathrm{p53}$, targeting them for proteasomal degradation as well. Indeed, Mdm2 has been shown to target a number of other proteins involved in cellcycle regulation and apoptosis.

The Ras/Raf/MEK/ERK pathway couples cell-surface receptor signals to transcription factors that regulate proliferation and differentiation, and mutations or alterations in this pathway are found in many human cancers [10]. When this pathway is activated, ERK phosphorylates Foxo3A, a transcription factor for cell-cycle regulatory proteins. In this phosphorylated form, Foxo3A becomes a target for ubiquitination by MDM2, promoting its degradation. As Foxo3 acts as a tumor suppressor, Mdm2-mediated down-regulation of 
Foxo3 could play a role in tumorigenesis in response to oncogenic growth factor signaling [70].

Additionally, Mdm2 has been shown to ubiquitinate the cell-adhesion protein E-cadherin and target it for degradation via the 26S proteasome [69]. E-cadherin has an extensively characterized role in the epithelial-to-mesenchymal transition that occurs when tumors initiate metastasis. Downregulation of E-cadherin causes a loss of cell polarity and cell-cell adhesion, and promotes cell motility and invasiveness; these in turn lead to invasion of the blood stream and metastasis. Interestingly, Mdm2 overexpression occurs more frequently in metastatic and recurrent tumors than it does in primary tumors [9, 28]. Overexpression of $\mathrm{Mdm} 2$ is also associated with a poor patient prognosis in a number of cancers [19, 24]. Thus, Mdm2 overexpression could potentially promote tumor invasion and metastasis through the downregulation of E-cadherin. However, whether or not this interaction is important in tumor progression has yet to be confirmed.

Paradoxically, Mdm2 has also been shown to target the transcription factor Slug for degradation. Slug (also known as SNAI1), is a member of the Snail family of transcriptional repressors. It is a key promoter of the epithelial-to-mesenchymal transition, which it stimulates by repressing the transcription of E-cadherin. This was shown to occur through a p53-Mdm2-Slug complex; interestingly, mutant and transcriptionally-inactive p53 inactivates the Mdm2-mediated degradation of Slug [64]. Although Mdm2 is normally thought of as an oncogene, its degradation of an invasion-promoting protein suggests that under certain circumstances, Mdm2 can also act as a tumor suppressor.

$\mathrm{Mdm} 2$ has also been shown to interact with the retinoblastoma protein ( $\mathrm{pRb})$, a tumor suppressor gene that, like p53, has a major role in cell-cycle inhibition and apoptosis. Unlike the Mdm2-p53 interaction, however, the Mdm2-pRb interaction is not mediated by ubiquitin ligation and degradation. In cells, Mdm2 forms a complex with $\mathrm{pRb}$ and disrupts the G1/S checkpoint by preventing $\mathrm{pRb}$ from binding to and inactivating certain members of the family of E2F transcription factors [68]. Interestingly, it has also been demonstrated that Mdm2 forms a trimeric pRb-Mdm2-p53 complex, with Mdm2 acting as a linker between these two transcription factors. Binding of $\mathrm{pRb}$ to $\mathrm{Mdm} 2$ does not inhibit $\mathrm{p} 53$ binding; this stands in contrast to other known regulators of the Mdm2-p53 interaction, such as p14 ${ }^{\mathrm{ARF}}$, which act by binding to Mdm2 and inhibiting p53 binding. The pRb-Mdm2 interaction is able to inhibit Mdm2-mediated p53 degradation, but does not remove the ability of Mdm2 to inhibit $\mathrm{p} 53$ transactivation of its target genes [18]. The finding that $\mathrm{pRb}$ impacts the apoptotic ability, but not the transcriptional activity of p53 suggests that the apoptotic effects of p53 may be independent of transactivation [71]. The discovery of cross-talk between the p53 and pRb pathways is particularly exciting, as these are arguably the two most important pathways in the prevention of tumorigenesis.

Mdm2 also impacts the pRb pathway through its interaction with E2F1 and DP1, transcription factors that heterodimerize and activate genes involved in the G1/S-phase transition. E2F1 contains a series of amino acids that are homologous to the activation domain of $\mathrm{p} 53$. In contrast to its negative regulation of $\mathrm{p} 53, \mathrm{Mdm} 2$ stimulates the transcriptional activity of E2F1/DP1, promoting progression into S phase [36]. In addition, 
Mdm2 increases degradation of the E2F1/DP1 complex, and can prevent p53-null cells from entering E2F-mediated apoptosis [32]. Thus, the Mdm2-E2F interaction both promotes cell growth through increased gene transcription and prevents cell death by inhibiting apoptosis, two activities that are hallmarks of tumorigenesis. However, whether or not the effect of $\mathrm{Mdm} 2$ on E2F1 is completely p53-independent is unclear. One study has suggested that this effect is mediated through inhibition of p53-dependent transcription of $\mathrm{p} 21$, the resultant increase in cyclin-dependent kinase activity causing phosphorylation/inactivation of $\mathrm{pRb}$, which in turn stimulates E2F1 activity $[12,66]$. These effects are not necessarily mutually exclusive; it is possible that this occurs through both p53-dependent and -independent mechanisms. The nature of the Mdm2-E2F1 relationship and its effect on cellular growth and tumorigenesis warrants further investigation.

The RING finger domain of Mdm2, which is responsible for its E3 ubiquitin ligase activity, also serves as a binding site for the closely related protein MdmX [59]. Mice lacking MdmX have similarity to Mdm2-knockout mice, in that both have an embryonic-lethal phenotype, although MdmX-null lethality occurs at a later stage of development and is associated with cell cycle arrest. Both phenotypes can be rescued by the loss of p53 [35, 48]. MdmX, despite possessing homology to the RING finger domain of Mdm2, does not possess E3-ubiquitin ligase activity. MdmX also represses p53, but does not do so through p53 degradation [25]. It has been suggested that Mdm2 homo-oligomers have different functions than Mdm2MdmX heterodimers and can modify each other's function and regulation. The growing evidence surrounding the Mdm2-MdmX-p53 triumvirate suggests a complex relationship between these proteins that modifies their functions, modifications, and stabilities [62]. The interaction between $\mathrm{Mdm} 2$ and $\mathrm{MdmX}$, and what role it plays in the regulation of p53depdendent and -independent effects of Mdm2, remains an active area of investigation.

\section{Mdm2 and Genome Instability}

Recently, increasing evidence has been found that suggests that Mdm2 overexpression can cause genome instability in a p53-independent manner. As already noted, targeted expression of Mdm2 to the mammary gland in transgenic mice gave the surprising phenotype of mammary epithelial cells that were hypertrophic and polyploid, indicating that these cells had undergone multiple rounds of $\mathrm{S}$ phase without mitosis. This effect was found to be p53-independent, as the same phenotype was observed in both wild-type and p53knockout backgrounds [34].

The Eischen laboratory has reported an interesting interaction between Mdm2 and Nbs1 (also called Nibrin or NBN), a member of the Mre11/Rad50/Nbs1 complex (more commonly referred to as MRN) that functions in initiating DNA double-strand break repair and activating cell-cycle checkpoints. Nbs1 is thought to localize the complex to doublestranded DNA breaks and play a role in activation of ATM signaling. Mdm2 overexpression in p53-null cells induced chromosome breakage and delayed DNA double-stranded break repair, but not in cells with a mutated form of Nbs1. Through mutational analysis of their respective binding domains, it was demonstrated that $\mathrm{Mdm} 2$ directly interacts with $\mathrm{Nbs} 1$ and inhibits its function, leading to a delayed DNA-damage response, possibly through reduction 
in ATM signaling. When this Mdm2-Nbs1 interaction is disrupted, the rate of DNA damage repair is restored [4].

Genomic instability is a common characteristic of many cancers [43]. Previous studies of Mdm2 overexpression had revealed that elevated Mdm2 levels led to increased chromosome/ chromatid breaks, centrosome hyperamplification, and aneuploidy [6, 63]. At that time, however, it was assumed these effects were mediated by Mdm2 repression of p53, as loss of p53 can also promote genome instability [8, 11, 31]. However, recent evidence, such as the demonstration of Mdm2 inhibition of Nbs1, argues that Mdm2 increases genetic instability directly and in a manner independent from the instability caused through inhibition of p53. This novel function of Mdm2 could have implications for cancer treatment, as it presents a new target interaction for chemotherapeutic drugs, as well as the appropriate clinical use of Mdm2 inhibitors such as Nutlin [4].

\section{Mdm2, Transcription, and Translation}

Although its primary role is involved the degradation of proteins, one unexpected function of $\mathrm{Mdm} 2$ that has been described is Mdm2-dependent regulation of translation. Mdm2 is known to regulate the translation of p53 via two different mechanisms. First, Mdm2 has been shown to directly interact with p53-encoding mRNA and impact its translation. Binding of p53-mRNA to the RING finger domain of Mdm2 stimulates translation of p53, while simultaneously inhibiting the E3 ligase ability of Mdm2 [42]. Fascinatingly, this suggests that while $\mathrm{Mdm} 2$ negatively regulates 553 on the protein level, it is a positive regulator of $\mathrm{p} 53$ on the mRNA level. In agreement with this, it has also been found that "silent" mutations of p53 - that is, nucleotide changes of the gene encoding p53 that do not change its amino acid sequence - have an impact on levels of p53 activity. Presumably, a silent mutation could alter the secondary structure of mRNA, thus altering its regulation by mRNA-binding proteins. This suggests that Mdm2-mRNA binding is an alternative method through which Mdm2 regulates p53 activity [5].

Secondly, Mdm2 has been shown to ubiquitinate and target the ribosomal protein RPL26 for degradation. RPL26 plays a critical role in the translation of p53-encoding mRNA following DNA damage [57]. Under normal conditions, Mdm2 targets RPL26 for degradation, secondarily prohibiting translation of $\mathrm{p} 53$. In response to DNA damage, the Mdm2 inhibition of RPL26 is attenuated, causing a rise in p53 translation [44].

Both of these mechanisms have been described as alternative methods by which Mdm2 regulates the activity of p53. In addition, they suggest additional mechanisms through which Mdm2 could regulate other cellular processes as well. Indeed, it has been recently been shown that Mdm2 binds to and stabilizes the mRNA encoding Slug. In p53-null cells, Mdm2 stabilization of Slug mRNA caused an increase in the amount of Slug protein and induced Slug-dependent effects, such as repression of E-cadherin and increased invasiveness [22]. The direct binding of Mdm2 to mRNA and altering its transcription is a novel mechanism by which Mdm2 could have tumorigenic effects independent of p53. 


\section{Future Directions}

In conclusion, $\mathrm{Mdm} 2$ has been shown to have a number of different functions independent of its role as a regulator of $\mathrm{p} 53$. Through the demonstration of alternate ubiquitination targets, its effects on genome stability, and interactions with mRNA and ribosomal proteins, it is becoming increasingly clear that $\mathrm{Mdm} 2$ regulates cellular processes on a number of different levels. Although these p53-independent functions are not fully understood, they may contribute to the role of $\mathrm{Mdm} 2$ in oncogenesis. As $\mathrm{Mdm} 2$ is implicated in a significant portion of human tumors, these functions present novel targets for potential clinical therapies. In order to provide a clinical benefit, however, the exact nature of these p53independent functions will need to be further characterized.

Based on current knowledge, several avenues of research need to be pursued. For one, over 40 different splice variants of the Mdm2 mRNA have been isolated from normal and tumor cells [3]. Studying the potentially distinct biological roles of these isoforms is likely to reveal more about the various functions of Mdm2. The finding that some human tumors express Mdm2 splice variants that lack the p53-binding domain suggests that these splice variants may contribute to oncogenesis through p53-independent effects [55]. One interesting area of further study would be to identify the effects of expressing these distinct splice variants in targeted tissues to determine what role they have in tumor development.

Additionally, given the variety of splice variants of Mdm2, a more rigorous analysis of Mdm2 overexpression in human cancers is warranted. Simple measurement of gene amplification or mRNA expression levels may not be truly reflective of the actual protein levels of $\mathrm{Mdm} 2$ and its variant forms in human tumors. A more detailed analysis that takes into account the existence of distinct isoforms will need to be performed in order to determine what isoforms are expressed in specific tumor types. Mdm2 overexpression seems to be associated with better prognosis in some tissue types, and worse prognosis in others [46]. However, these analyses have, for the most part, used methods that do not distinguish between splice variants. Comparing the expression of distinct isoforms in tumor samples with clinical outcome data could reveal whether or not Mdm2 isoforms have an effect on patient prognosis and potentially explain this paradoxical finding.

Nutlin-3 has been investigated for use as an agent that disrupts the Mdm2-p53 interaction. However, as a small-molecule inhibitor of Mdm2, it also has the potential to inhibit or alter p53-independent effects of Mdm2 as well. It has been shown that Nutlin-3 can increase cell toxicity following DNA damage in p53-null prostate cancer cells, where it acts as a radiosensitizer [56]. Recently, Nutlin-3 has also been shown to inhibit the epithelial-tomesenchymal transition in 553 -null cells by interfering with the TGF- $\beta 1$-SmadSnail/Slug axis [65]. The exact mechanisms by which Nutlin-3 exerts p53-independent effects remain unclear. Such findings have important clinical relevance: traditional thinking would indicate that drugs such as Nutlin would only be clinically useful in cancers that retain wild-type p53. However, if Mdm2 inhibitors are found to interfere with the tumor-promoting, p53independent effects of $\mathrm{Mdm} 2$, they could potentially be useful as chemotherapeutic agents in a much wider spectrum of tumors. 
Given the central role of p53 in tumor suppression, it is unsurprising that most research on $\mathrm{Mdm} 2$ has been focused on its regulation of $\mathrm{p} 53$. Nevertheless, a growing body of evidence suggests that Mdm2 has a number of other p53-independent functions, both in normal cellular biology and tumorigenesis. The exact mechanism of these functions, under which conditions they occur, and their significance to oncogenesis have yet to be determined. As Mdm2 emerges as an important player in tumor development in its own right, fully characterizing its p53-independent functions will certainly be important in the study of tumor biology and the development of new therapies for the treatment of cancer.

\section{References}

1. Appella E, Anderson CW. Post-translational modifications and activation of p53 by genotoxic stresses. Eur J Biochem. 2001; 268:2764-2772. [PubMed: 11358490]

2. Bartel F, Taylor AC, Taubert H, Harris LC. Novel mdm2 splice variants identified in pediatric rhabdomyosarcoma tumors and cell lines. Oncol Res. 2001; 12:451-457. [PubMed: 11939408]

3. Bartel F, Taubert H, Harris LC. Alternative and aberrant splicing of MDM2 mRNA in human cancer. Cancer Cell. 2002; 2:9-15. [PubMed: 12150820]

4. Bouska A, Lushnikova T, Plaza S, Eischen CM. Mdm2 promotes genetic instability and transformation independent of p53. Mol Cell Biol. 2008; 28:4862-4874. [PubMed: 18541670]

5. Candeias MM, Malbert-Colas L, Powell DJ, Daskalogianni C, Maslon MM, Naski N, Bourougaa K, Calvo F, Fåhraeus R. P53 mRNA controls p53 activity by managing Mdm2 functions. Nat Cell Biol. 2008; 10:1098-105. [PubMed: 19160491]

6. Carroll PEP, Okuda MM, Horn HFH, Biddinger PP, Stambrook PJP, Gleich LLL, Li YQY, Tarapore PP, Fukasawa KK. Centrosome hyperamplification in human cancer: chromosome instability induced by p53 mutation and/or Mdm2 overexpression. Oncogene. 1999; 18:1935-1944. [PubMed: 10208415]

7. Cordon-Cardo C, Latres E, Drobnjak M, Oliva MR, Pollack D, Woodruff JM, Marechal V, Chen J, Brennan MF, Levine AJ. Molecular abnormalities of mdm2 and p53 genes in adult soft tissue sarcomas. Cancer Res. 1994; 54:794-799. [PubMed: 8306343]

8. Dalton WBW, Yu BB, Yang VWV. p53 suppresses structural chromosome instability after mitotic arrest in human cells. Oncogene. 2010; 29:1929-1940. [PubMed: 20062083]

9. Datta MW, Macri E, Signoretti S, Renshaw AA, Loda M. Transition from in situ to invasive testicular germ cell neoplasia is associated with the loss of p21 and gain of mdm-2 expression. Mod Pathol. 2001; 14:437-442. [PubMed: 11353054]

10. Davies H, Bignell GR, Cox C, Stephens P, Edkins S, Clegg S, Teague J, Woffendin H, Garnett MJ, Bottomley W, et al. Mutations of the BRAF gene in human cancer. Nature. 2002; 417:949-954. [PubMed: 12068308]

11. Donehower LA, Godley LA, Aldaz CM, Pyle R, Shi YP, Pinkel D, Gray J, Bradley A, Medina D, Varmus HE. Deficiency of p53 accelerates mammary tumorigenesis in Wnt-1 transgenic mice and promotes chromosomal instability. Genes Dev. 1995; 9:882-895. [PubMed: 7705663]

12. Ganguli G, Wasylyk B. p53-independent functions of MDM2. Mol Cancer Res. 2003; 1:10271035. [PubMed: 14707286]

13. Giono LE, Manfredi JJ. Mdm2 is required for inhibition of Cdk2 activity by p21, thereby contributing to p53-dependent cell cycle arrest. Mol Cell Biol. 2007; 27:4166-4178. [PubMed: 17371838]

14. Haines DS, Landers JE, Engle LJ, George DL. Physical and functional interaction between wildtype p53 and mdm2 proteins. Mol Cell Biol. 1994; 14:1171-1178. [PubMed: 8289798]

15. Haupt Y, Maya R, Kazaz A, Oren M. Mdm2 promotes the rapid degradation of p53. Nature. 1997; 387:296-299. [PubMed: 9153395]

16. Hollstein M, Sidransky D, Vogelstein B, Harris CC. p53 mutations in human cancers. Science. 1991; 253:49-53. [PubMed: 1905840] 
17. Honda R, Tanaka H, Yasuda H. Oncoprotein MDM2 is a ubiquitin ligase E3 for tumor suppressor p53. FEBS Lett. 1997; 420:25-27. [PubMed: 9450543]

18. Hsieh JK, Chan F, O'Connor DJ, Mittnacht S. RB regulates the stability and the apoptotic function of p53 via MDM2. Mol Cell. 1999; 3:181-193. [PubMed: 10078201]

19. Ikeguchi M, Ueda T, Fukuda K, Yamaguchi K-I, Tsujitani S-I, Kaibara N. Expression of the murine double minute gene 2 oncoprotein in esophageal squamous cell carcinoma as a novel marker for lack of response to chemoradiotreatment. Am J Clin Oncol. 2002; 25:454-459. [PubMed: 12393983]

20. Jones SN, Roe AE, Donehower LA, Bradley A. Rescue of embryonic lethality in Mdm2-deficient mice by absence of p53. Nature. 1995; 378:206-208. [PubMed: 7477327]

21. Jones SN, Hancock AR, Vogel H, Donehower LA, Bradley A. Overexpression of Mdm2 in mice reveals a p53-independent role for Mdm2 in tumorigenesis. Proc Natl Acad Sci. 1998; 95:1560815612. [PubMed: 9861017]

22. Jung C-H, Kim J, Park JK, Hwang S-G, Moon S-K, Kim W-J, Um H-D. Mdm2 increases cellular invasiveness by binding to and stabilizing the Slug mRNA. Cancer Lett. 2013; 335:270-277. [PubMed: 23438693]

23. Juven T, Barak Y, Zauberman A, George DL, Oren M. Wild type p53 can mediate sequencespecific transactivation of an internal promoter within the mdm2 gene. Oncogene. 1993; 8:34113416. [PubMed: 8247544]

24. Korkolopoulou P, Christodoulou P, Kapralos P, Exarchakos M, Bisbiroula A, Hadjiyannakis M, Georgountzos C, Thomas-Tsagli E. The role of p53, MDM2 and c-erb B-2 oncoproteins, epidermal growth factor receptor and proliferation markers in the prognosis of urinary bladder cancer. Pathol Res Pract. 1997; 193:767-775. [PubMed: 9521509]

25. Kruse J-P, Gu W. Modes of p53 regulation. Cell. 2009; 137:609-622. [PubMed: 19450511]

26. Kubbutat MH, Jones SN, Vousden KH. Regulation of p53 stability by Mdm2. Nature. 1997; 387:299-303. [PubMed: 9153396]

27. Künkele A, De Preter K, Heukamp L, Thor T, Pajtler KW, Hartmann W, Mittelbronn M, Grotzer MA, Deubzer HE, Speleman F, et al. Pharmacological activation of the p53 pathway by nutlin-3 exerts anti-tumoral effects in medulloblastomas. Neuro-Oncology. 2012; 14:859-869. [PubMed: 22591662]

28. Ladanyi M, Cha C, Lewis R, Jhanwar SC, Huvos AG, Healey JH. MDM2 gene amplification in metastatic osteosarcoma. Cancer Res. 1993; 53:16-18. [PubMed: 8416741]

29. Lahav G. Oscillations by the p53-Mdm2 feedback loop. Adv Exp Med Biol. 2008; 641:28-38. [PubMed: 18783169]

30. Leach FS, Tokino T, Meltzer P, Burrell M, Oliner JD, Smith S, Hill DE, Sidransky D, Kinzler KW, Vogelstein B. p53 mutation and MDM2 amplification in human soft tissue sarcomas. Cancer Res. 1993; 53:2231-2234. [PubMed: 8387391]

31. Lengauer C, Kinzler KW, Vogelstein B. Genetic instabilities in human cancers. Nature. 1998; 396:643-649. [PubMed: 9872311]

32. Loughran O, La Thangue NB. Apoptotic and growth-promoting activity of E2F modulated by MDM2. Mol Cell Biol. 2000; 20:2186-2197. [PubMed: 10688665]

33. Lukas J, Gao DQ, Keshmeshian M, Wen WH, Tsao-Wei D, Rosenberg S, Press MF. Alternative and aberrant messenger RNA splicing of the $\mathrm{mdm} 2$ oncogene in invasive breast cancer. Cancer Res. 2001; 61:3212-3219. [PubMed: 11306511]

34. Lundgren K, Montes de Oca Luna R, McNeill YB, Emerick EP, Spencer B, Barfield CR, Lozano G, Rosenberg MP, Finlay CA. Targeted expression of MDM2 uncouples S phase from mitosis and inhibits mammary gland development independent of p53. Genes Dev. 1997; 11:714-725. [PubMed: 9087426]

35. Marine J-C, Francoz S, Maetens M, Wahl G, Toledo F, Lozano G. Keeping p53 in check: essential and synergistic functions of Mdm2 and Mdm4. Cell Death Differ. 2006; 13:927-934. [PubMed: 16543935]

36. Martin K, Trouche D, Hagemeier C, Sørensen TS, La Thangue NB, Kouzarides T. Stimulation of E2F1/DP1 transcriptional activity by MDM2 oncoprotein. Nature. 1995; 375:691-694. [PubMed: 7791903] 
37. Matsumoto R, Tada M, Nozaki M, Zhang CL, Sawamura Y, Abe H. Short alternative splice transcripts of the $\mathrm{mdm} 2$ oncogene correlate to malignancy in human astrocytic neoplasms. Cancer Res. 1998; 58:609-613. [PubMed: 9485008]

38. Mendrysa SMS, Perry MEM. The p53 tumor suppressor protein does not regulate expression of its own inhibitor, MDM2, except under conditions of stress. Mol Cell Biol. 2000; 20:2023-2030. [PubMed: 10688649]

39. Momand J, Zambetti GP, Olson DC, George D, Levine AJ. The mdm-2 oncogene product forms a complex with the p53 protein and inhibits p53-mediated transactivation. Cell. 1992; 69:12371245. [PubMed: 1535557]

40. Momand J, Jung DD, Wilczynski SS, Niland JJ. The MDM2 gene amplification database. Nucleic Acids Res. 1998; 26:3453-3459. http://eutils.ncbi.nlm.nih.gov/entrez/eutils/elink.fcgi? dbfrom=pubmed\&id=9671804\&retmode=ref\&cmd=prlinks. [PubMed: 9671804]

41. Montes de Oca Luna R, Wagner DS, Lozano G. Rescue of early embryonic lethality in mdm2deficient mice by deletion of p53. Nature. 1995; 378:203-206. [PubMed: 7477326]

42. Naski N, Gajjar M, Bourougaa K, Malbert-Colas L, Fåhraeus R, Candeias M. The p53 mRNAMdm2 interaction. Cell Cycle. 2009; 8:31-34. [PubMed: 19106616]

43. Negrini S, Gorgoulis VG, Halazonetis TD. Genomic instability - an evolving hallmark of cancer. Nat Rev Mol Cell Biol. 2010; 11:220-228. [PubMed: 20177397]

44. Ofir-Rosenfeld Y, Boggs K, Michael D, Kastan MB, Oren M. Mdm2 regulates p53 mRNA translation through inhibitory interactions with ribosomal protein L26. Mol Cell. 2008; 32:180189. [PubMed: 18951086]

45. Oliner JD, Kinzler KW, Meltzer PS, George DL, Vogelstein B. Amplification of a gene encoding a p53-associated protein in human sarcomas. Nature. 1992; 358:80-83. http:// eutils.ncbi.nlm.nih.gov/entrez/eutils/elink.fcgi? dbfrom $=$ pubmed $\&$ id $=1614537 \&$ retmode $=$ ref $\& \mathrm{cmd}=$ prlinks. [PubMed: 1614537]

46. Onel K, Cordon-Cardo C. MDM2 and prognosis. Mol Cancer Res. 2004; 2:1-8. [PubMed: 14757840]

47. Pant V, Xiong S, Jackson JG, Post SM, Abbas HA, Quintás-Cardama A, Hamir AN, Lozano G. The p53-Mdm2 feedback loop protects against DNA damage by inhibiting p53 activity but is dispensable for p53 stability, development, and longevity. Genes Dev. 2013; 27:1857-1867. [PubMed: 23973961]

48. Parant JJ, Chavez-Reyes AA, Little NAN, Yan WW, Reinke VV, Jochemsen AGA, Lozano GG. Rescue of embryonic lethality in Mdm4-null mice by loss of Trp53 suggests a nonoverlapping pathway with MDM2 to regulate p53. Nat Genet. 2001; 29:92-95. [PubMed: 11528400]

49. Ponnuswamy AA, Hupp TT, Fåhraeus RR. Concepts in MDM2 signaling: allosteric regulation and feedback loops. Genes Cancer. 2012; 3:291-297. [PubMed: 23150762]

50. Sam KK, Gan CP, Yee PS, Chong CE, Lim KP, Karen-Ng LP, Chang WS, Nathan S, Rahman ZAA, Ismail SM, et al. Novel MDM2 splice variants identified from oral squamous cell carcinoma. Oral Oncol. 2012; 48:1128-1135. [PubMed: 22705356]

51. Saucedo LJL, Carstens BPB, Seavey SES, Albee LDL, Perry MEM. Regulation of transcriptional activation of mdm2 gene by p53 in response to UV radiation. Cell Growth Differ. 1998; 9:119130. [PubMed: 9486848]

52. Secchiero P, Bosco R, Celeghini C, Zauli G. Recent advances in the therapeutic perspectives of Nutlin-3. Curr Pharm Des. 2011; 17:569-577. [PubMed: 21391907]

53. Sherr CJ. Divorcing ARF and p53: an unsettled case. Nat Rev Cancer. 2006; 6:663-673. [PubMed: 16915296]

54. Shieh SY, Ikeda M, Taya Y, Prives C. DNA damage-induced phosphorylation of p53 alleviates inhibition by MDM2. Cell. 1997; 91:325-334. [PubMed: 9363941]

55. Sigalas I, Calvert AH, Anderson JJ, Neal DE, Lunec J. Alternatively spliced mdm2 transcripts with loss of p53 binding domain sequences: transforming ability and frequent detection in human cancer. Nat Med. 1996; 2:912-917. [PubMed: 8705862]

56. Supiot SS, Hill RPR, Bristow RGR. Nutlin-3 radiosensitizes hypoxic prostate cancer cells independent of p53. Mol Cancer Ther. 2008; 7:993-999. [PubMed: 18413812] 
57. Takagi M, Absalon MJ, McLure KG, Kastan MB. Regulation of p53 translation and induction after DNA damage by ribosomal protein L26 and nucleolin. Cell. 2005; 123:49-63. [PubMed: 16213212]

58. Tang Y, Zhao W, Chen Y, Zhao Y, Gu W. Acetylation is indispensable for p53 activation. Cell. 2008; 133:612-626. [PubMed: 18485870]

59. Tanimura SS, Ohtsuka SS, Mitsui KK, Shirouzu KK, Yoshimura AA, Ohtsubo MM. MDM2 interacts with MDMX through their RING finger domains. FEBS Lett. 1999; 447:5-9. [PubMed: 10218570]

60. Taubert H, Bartel F, Greither T, Bache M, Kappler M, Köhler T, Böhnke A, Lautenschläger C, Schmidt H, Holzhausen H-J, et al. Association of HDM2 transcript levels with age of onset and prognosis in soft tissue sarcomas. Mol Cancer Res. 2008; 6:1575-1581. [PubMed: 18922973]

61. Vassilev LT, Vu BT, Graves B, Carvajal D, Podlaski F, Filipovic Z, Kong N, Kammlott U, Lukacs $\mathrm{C}$, Klein $\mathrm{C}$, et al. In vivo activation of the p53 pathway by small-molecule antagonists of MDM2. Science. 2004; 303:844-848. [PubMed: 14704432]

62. Wade M, Wang YV, Wahl GM. The p53 orchestra: Mdm $\beta 2$ and Mdmx set the tone. Trends Cell Biol. 2010; 20:299-309. [PubMed: 20172729]

63. Wang P, Lushnikova T, Odvody J, Greiner TC, Jones SN, Eischen CM. Elevated Mdm2 expression induces chromosomal instability and confers a survival and growth advantage to B cells. Oncogene. 2008; 27:1590-1598. [PubMed: 17828300]

64. Wang S-P, Wang W-L, Chang Y-L, Wu C-T, Chao Y-C, Kao S-H, Yuan A, Lin C-W, Yang S-C, Chan W-K, et al. p53 controls cancer cell invasion by inducing the MDM2-mediated degradation of Slug. Nat Cell Biol. 2009; 11:694-704. [PubMed: 19448627]

65. Wu Y, Fu Y, Zheng L, Lin G, Ma J, Lou J, Zhu H, He Q, Yang B. Nutlin-3 inhibits epithelialmesenchymal transition by interfering with canonical transforming growth factor $\beta 1$-Smad-Snail/ Slug axis. Cancer Lett. 2014; 342:82-91. [PubMed: 24001610]

66. Wunderlich M, Berberich SJ. Mdm2 inhibition of $\mathrm{p} 53$ induces E2F1 transactivation via p21. Oncogene. 2002; 21:4414-4421. [PubMed: 12080472]

67. Würl P, Meye A, Schmidt H, Lautenschläger C, Kalthoff H, Rath FW, Taubert H. High prognostic significance of Mdm2/p53 co-overexpression in soft tissue sarcomas of the extremities. Oncogene. 1998; 16:1183-1185. [PubMed: 9528860]

68. Xiao ZX, Chen J, Levine AJ, Modjtahedi N, Xing J, Sellers WR, Livingston DM. Interaction between the retinoblastoma protein and the oncoprotein MDM2. Nature. 1995; 375:694-698. [PubMed: 7791904]

69. Yang J-Y, Zong CS, Xia W, Wei Y, Ali-Seyed M, Li Z, Broglio K, Berry DA, Hung M-C. MDM2 promotes cell motility and invasiveness by regulating E-cadherin degradation. Mol Cell Biol. 2006; 26:7269-7282. [PubMed: 16980628]

70. Yang J-YJ, Zong CSC, Xia WW, Yamaguchi HH, Ding QQ, Xie XX, Lang J-YJ, Lai C-CC, Chang C-JC, Huang W-CW, et al. ERK promotes tumorigenesis by inhibiting FOXO3a via MDM2mediated degradation. Nat Cell Biol. 2008; 10:138-148. [PubMed: 18204439]

71. Yap DB, Hsieh JK, Chan FS, Lu X. mdm2: a bridge over the two tumour suppressors, p53 and Rb. Oncogene. 1999; 18:7681-7689. [PubMed: 10618708]

72. Zhang Y, Lu H. Signaling to p53: ribosomal proteins find their way. Cancer Cell. 2009; 16:369377. [PubMed: 19878869] 